\title{
Geographic Patterns in Temperate American Ferns and Some Relationships in Thelypteris
}

\author{
ALICE TRYON and ROLLA TRYON*,1
}

Detailed studies of species along with analyses of floristic ensembles have resulted in a better understanding of the history of the flora of the United States and Canada. This study of the chromosomes, spores, and geographic relationships of Thelypteris nevadensis (D.C. Eaton) Morton illustrates how such diverse data can be synthesized and are applicable to broader phytogeographic concepts. This fern of moist, open meadows and wooded slopes ranges from southern British Columbia to central California and geographically is a critical species. Its closest relative is T. noveboracensis (L.) Nieuwl. of eastern North America; also it is related to other species of eastern Asia. Geographic analyses of these American species and other taxa having similar Cordilleran-Appalachian ranges show predominantly circumboreal affinities. There is a lesser element among the North American mesic ferns that has geographic relations with tropical regions. The cytological and palynological data illustrated here document basic information useful in establishing evolutionary lines and supplement other evidence pertaining to the geography and migration of species. This study has developed out of previous work on the alliance of three species of Thelypteris in north-eastern America (Tryon \& Tryon, 1973).

\section{CYTOLOGY}

Thelypteris nevadensis has been reported to have chromosome numbers of $n=26$ and $n=27$ (Taylor \& Lang, 1963), based on material from Vancouver Island, British Columbia. In that work the variability of the species is noted as, "sometimes giving counts of 26 and sometimes 27 , which is a matter that should be investigated further." A gametic number for the species has been reported as 27 by A. R. Smith (1971) from collections made in Fresno County, California. In this publication, Smith regards the earlier report of $n=26$ as unlikely, although he cites "T. nevadensis ( $n=26$ or 27)." Photographic records of these earlier reports have not been published. We have studied the meiotic chromosomes in material from the Cascades of Oregon, which clearly has 27 pairs (Fig. 1).

In Thelypteris there are reports establishing several chromosome numbers, among which $n=36$ is the most frequent and seems to be the basic number for the genus. In Thelypteris palustris Schott there are documented records of $n=35$ over the range of the species in eastern North America, Europe and Japan. A series of numbers, ranging from $n=29$ to $n=32$, is also reported for other species of Thelypteris. These numbers suggest that chromosome deletion may have had an important role in evolution within the genus. There is a need for further cytological work in certain critical species to establish evidence for this. Thelypteris

\footnotetext{
*Department of Biology and Gray Herbarium, Harvard University, Cambridge, MA 02138.

${ }^{1}$ We are grateful to Neill D. Hall for the material of Thelypteris nevadensis from the Cascades of Oregon, illustrated here. We are also appreciative for plants from British Columbia sent by Dr. T. M. C. Taylor. We are grateful to the Jeol Company, Medford, Mass. for use of the JSM-35 instrument and especially for the work of Aki Kabaya.
} 
nevadensis may be one of the species in which cytological analyses of populations will yield data on aneuploidy. The earlier report of $n=26$ may be an accurate rather than an erroneous one due to difficult material. Additional work on the populations of Vancouver Island should easily resolve this matter. The report of $n=36$ in T. palustris from Japan has been altered to $n=35$ (Tryon \& Tryon, 1973), but further study should be made of populations of that species throughout its range in Asia, as well as in Africa and New Zealand.
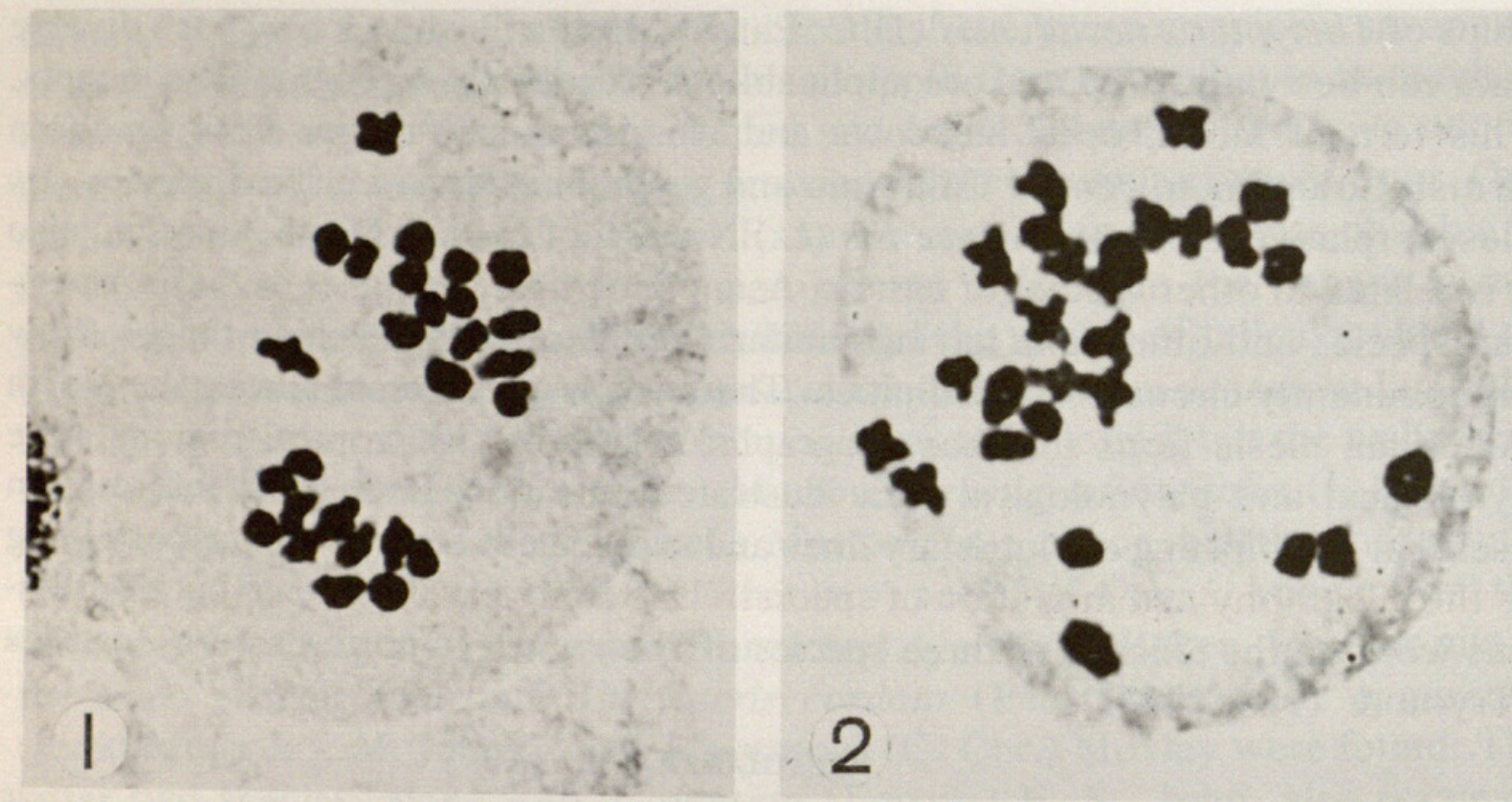

Meiotic chromosomes of Thelypteris with 27 bivalents, $\times 1300$. FIG. 1. T. nevadensis, N. D. Hall in 1973, east of Salem, Cascade Mts., Oregon (GH). FIG. 2. T. noveboracensis, A. Tryon 69-5, Lincoln, Mass. (GH).

The report of $n=27$ in Thelypteris noveboracensis, as shown in Fig. 2, is consistent with other records for the species over its range in North America. Previous reports are summarized in our earlier work, cited above. The occurrence of the gametic chromosome number 27 is unique among American species of Thelypteris. It is known in only one other species, T. cystopteroides (D. C. Eaton) Ching (S. Kawakami, pers. comm. 1973), a rare species of Japan and the Ryukyu Islands. Although $T$. nevadensis and $T$. noveboracensis are clearly related, this third species is quite distinct. As the specific epithet implies, it is a smaller plant with the leaf architecture of Cystopteris fragilis. The leaves are almost glabrous, about $10 \mathrm{~cm}$ long, and the rhizomes are very slender and longcreeping. A detailed description of the species is given by Iwatsuki (1965, pp. 169-170). A basic question in Thelypteris cytology is whether the low number 27 is primitive and monophyletic or whether it is derived and possibly polyphyletic. The solution evidently lies among related species of eastern Asia, especially those recently placed in Parathelypteris by Holttum (1971). This group includes, among others: Thelypteris glanduligera (Kunze) Ching, with $n=72$, and T. nipponica (Franch. \& Sav.) Ching and T. japonica (Baker) Ching, with $n=62$. Thelypteris beddomei (Bak.) Ching and T. japonica var. musashiensis Hiyama are reported with $n=31$, and $T$. cystopteroides has $n=27$. 


\section{SPORES}

A new era in palynology has been initiated by the recent electron microscope studies of spores. Information revealed in scanning electron microscope photographs makes detailed descriptions superfluous and, indeed, emphasizes the lack of appropriate terminology. The study of spores of thirty species with the transmission electron microscope by B. Lugardon (1972) illustrates the complexity and variation in wall stratification. The SEM survey of the spores of Thelypteridaceae by C. Wood (1973), as well as our earlier work noted below, shows that surface patterns of spores have utility in systematic work.

The spores examined here are from herbarium specimens. They were prepared as indicated by methods described in detail earlier (A. F. Tryon, 1971), consisting of underlaying with carbon prior to coating with an alloy of palladium-gold. The work was done with an AMR-900 instrument at the Gordon McKay Laboratories of Applied Science, Harvard University, and also with a JSM-35 instrument (designated by $\mathrm{J}$ in the figure legends). The basic similarities in surface structure of the spores of Thelypteris nevadensis and $T$. noveboracensis are evident in Figs. 3-8. The reticulum is less regular in the spores of T. nevadensis (Fig. 5), with ridges both appressed and projecting from the surface. In Fig. 3 the commissural ridge extends more than half the length of the spore. Thelypteris noveboracensis spores in Figs. 6-8 have a more prominent and uniform reticulum. The surface texture of some of the ridges as well as the underlying strata is apparent at the right of Fig. 8. The pattern of strongly reticulate ridges in these spores is similar to that of $T$. nipponica (Tryon \& Tryon, 1973).

Wood's (1973) classification of Thelypteridaceae spores contains two basic groups: Type 1-Winged or Ridged, and Type 2-Reticulate. Each of these groups is subdivided into several classes. In this system the spores of Thelypteris nevadensis were included in the Reticulate group in the subdivision Reticulum spiny, which is described as, "Simple spines with ridged bases running together to form a reticulum adpressed to the underlying sporodermal surface." Spores of $T$. nipponica were placed in the first group among those with Winged sporoderm and in the subdivision described as, "Wings narrow, may be nearly membranous, usually with crenate or fimbriate crests. The wings may be tall or short and anastomosis of wings is common." The spores of $T$. noveboracensis were not included in this survey, but evidently they belong in the Reticulate group along with those of $T$. nevadensis. The great variety of surface structure among these thelypteroid spores includes such diverse forms described as winged, spiny, reticulate, and verrucate. These different types represent some of the subdivisions within the two major groups recognized by Wood. The information from these SEM studies raises more complex problems on the physiological development and evolutionary relations of the different forms. It appears that the diversity in spore structure may be a function of developmental physiology, rather than adaptation for dispersal. Marked differences also occur within species, as shown by variations of the sporoderm structure in T. palustris (A. F. Tryon, 1971) and in "Dryopteris campyloptera," noted by Britton (1972). Also compare the spores of T. noveboracensis in Figs. 6 and 7 illustrated here. 

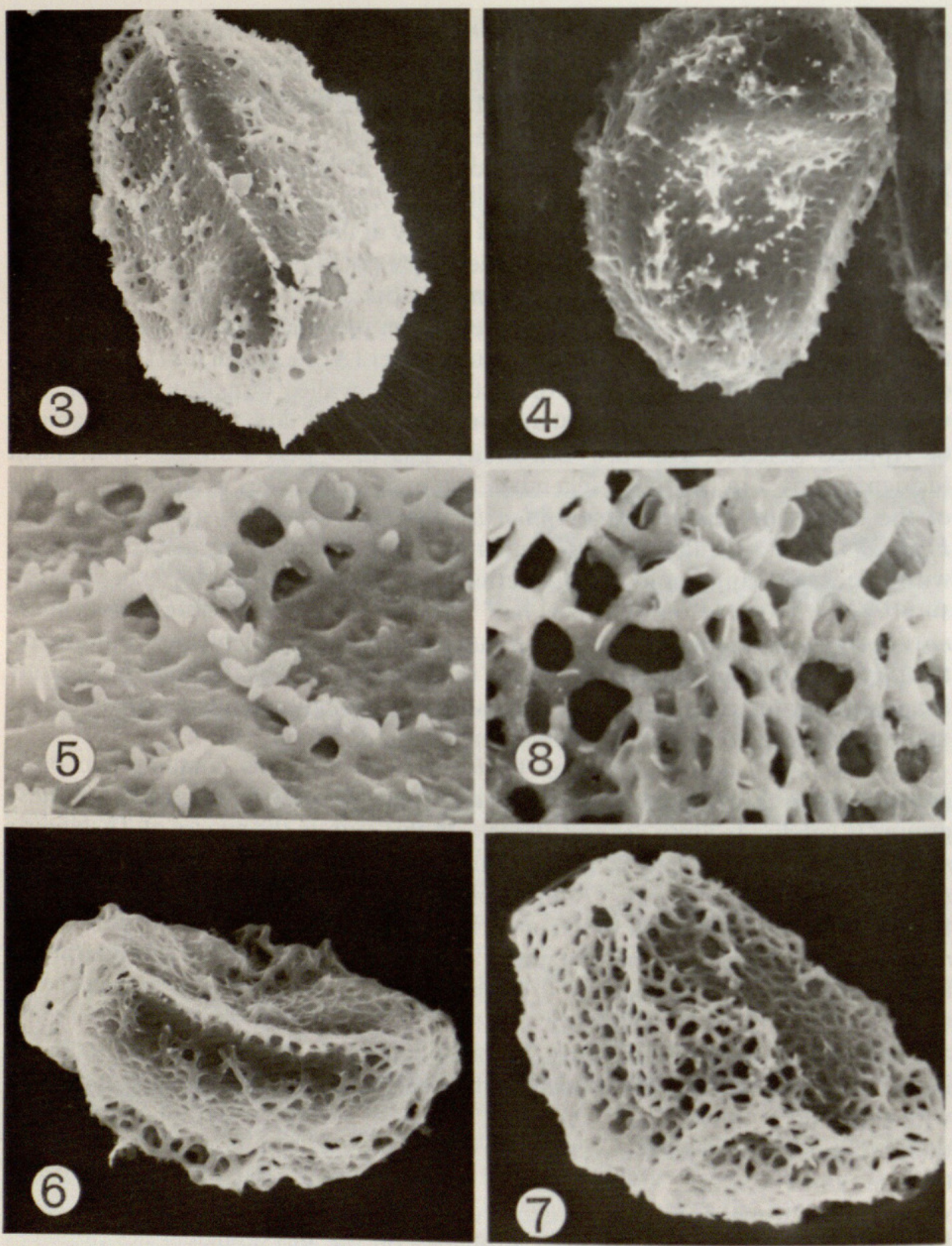

Thelypteris spores. FIGS. 3-5. T. nevadensis, N. D. Hall in 1973, east of Salem, Cascade Mts., Oregon (GH). Reticulate perispore. FIG. 3. The commissural ridge diagonal and eroded perispore at lower right, ca. $\times 1300$. FIG. 4 . Spore with strongly appressed reticulum, ca. $\times 1300$. FIG. 5 . Perispore detail, ca. $\times 6000$. FIGS. 6-8. T. noveboracensis, A. Tryon 69-5, Lincoln, Mass. (GH). Reticulate perispore. FIG. 6. The commissural ridge slightly above center, ca. $\times 1300$. FIG. 7. Spore with strongly projecting reticulum, ca. $\times 1300,(J)$. FIG. 8. Perispore detail, irregular surface within areolae, top right, ca. $\times 5000$. 


\section{GEOGRAPHY}

Thelypteris nevadensis, ranging from southern British Columbia to central California, and $T$. noveboracensis, ranging from Newfoundland west to Wisconsin and south to Georgia and Louisiana, represent the well known CordilleranAppalachian floristic affinity among North American plants. Another similar vicarious species pair in ferns is Dryopteris arguta (Kaulf.) Watt (western) and $D$. marginalis (L.) A. Gray (eastern). These disjunct relations are also evident in the geographic distribution of varieties, as in Polystichum braunii (Spenner) Fée var. alaskense (Maxon) Hult. (western) and var. purshii Fern. (eastern). They also occur in single taxa which may be disjunct, as in Athyrium distentifolium Tausch [A. alpestre (Hoppe) Moore] and Dryopteris cristata (L.) A. Gray, or in those which have more or less continuous ranges, especially across the north, as in Cystopteris montana (Lam.) Bernh. and Thelypteris phegopteris (L.) Slosson.

Analysis of the floristic ensembles of ferns of the United States and Canada reveals some basic geographic information. Nearly all species with CordilleranAppalachian relations have broader circumboreal geographic affinities involving the same species or species groups also occurring in eastern Asia and/or in Europe. The dominant element among the mesic ferns of the United States and Canada has circumboreal relations. The mesic tropical species have not contributed significantly to our temperate or boreal fern flora, although there is a very rich reservoir of species immediately to the south. The principal tropical ferns in the United States are the West Indian element, strongly represented in Florida, and the Mexican xeric element, centering in the southwest from Texas to southern California. The basis for this dominance of circumboreal ferns in our flora is undoubtedly related to the series of continental glaciations and intervening mild interglacial periods during the Pleistocene. The poor representation of species of the wet tropics is quite possibly due to their requirement for gradual adaptations to more northern climates, which would not be met by the oscillating extremes during continental glaciation.

The boreal elements of the fern flora of North America, on the other hand, have been intimately involved with Pleistocene history. In contrast to a tropical fern flora, an originally more northern one, for example, in eastern Asia, would be well adapted to migration during interglacial periods, and some species would have the capacity for cold adaptation. Migration of species from eastern Asia could result in broad distributions in North America during an interglacial period. During the glacial maximum the ranges would be restricted south of the ice and especially to the east and west of the northern great plains. During the following interglacial, migration northward of some of the species would re-establish continuous ranges. Those species less cold-adapted would migrate little if at all and would remain geographically isolated. Divergence among these isolated populations could account for the differences in vicarious species pairs such as $T$. nevadensis and $T$. noveboracensis. The similarities that have been shown here between these species in chromosome number and surface structure of the spores indicate a relatively close relationship. This also suggests that their present Cordilleran and Appalachian floristic patterns may represent a relatively late geographic disjunction. 


\section{LITERATURE CITED}

BRITTON, D. M. 1973. Spore ornamentation in the Dryopteris spinulosa complex. Canad. J. Bot. 50: $1617-1621$.

HOLTTUM, R. E. 1971. Studies in the family Thelypteridaceae III. A new system of genera in the old world. Blumea 19: 17-52.

IWATSUKI, K. 1965. Taxonomy of thelypteroid ferns, with special reference to the species of Japan and adjacent regions. IV. Univ. Kyoto Mem. Biol. 31: 125-197.

LUGARDON, B. 1972. Contribution à la connaissance de la morphogenèse et de la structure des parois sporales chez les Filicinées isosporées. Thesis 458, Univ. Paul Sabatier de Toulouse, France. 257 pp. 51 plates.

SMITH, A. R. 1971. Chromosome numbers of some new world species of Thelypteris. Brittonia 23: 354-360.

TAYLOR, T. M. C. and F. LANG. 1963. Chromosome counts in some British Columbia ferns. Amer. Fern J. 53: 123-126.

TRYON, A. F. 1971. Structure and variation in spores of Thelypteris palustris. Rhodora 73: 444-460. , and R. TRYON. 1973. Thelypteris in northeastern North America. Amer. Fern J. 63: 65-76.

WOOD, C. C. 1973. Spore variation in the Thelypteridaceae in A. C. Jermy et al. (eds). The Phylogeny and Classification of the Ferns. Bot. J. Linn. Soc. London 67 Suppl. 1: 191-202.

\section{Boughton Cobb (1894-1974)}

Boughton Cobb was born in Lake Forest, Illinois, on June 18, 1894. His early years were spent in a rural community, where his love for the world of nature began. His family moved to Washington, DC when Boughton was still young. He liked to hunt and fish, but gradually his enthusiasm for observing nature pushed those earlier interests aside. He graduated from Harvard in 1915 and then trained as an architect at the Columbia School of Architecture. After serving in World War I, he engaged in a successful business career in textiles, from which he retired in 1960. The Cobbs had a summer home-later their permanent residence-in Falls Village, Connecticut, where Boughton was widely known and active in community affairs. The Cobb's attractive house had a terrace overlooking a fern-bordered brook. Boughton maintained a large collection of hardy American ferns and had a greenhouse for experimenting with unusual ferns. In the preparation of his book "A Field Guide to the Ferns," which was illustrated by his neighbor Laura Louise (Mrs. H. Lincoln) Foster, he spent two months ferning in the British Isles and visited several sections of this country. He participated in several forays and meetings of the American Fern Society, of which he was a life member. He died January 13, 1974, in New York City, leaving Mrs. Cobb (the former Edith McKeever), a son, a daughter, and seven grandchildren.-Benjamin R. Allison, Hewlett, Long Island, NY 11557. 


\section{$2 \mathrm{BHL}$ Biodiversity Heritage Library}

Tryon, Alice F. and Tryon, Rolla M. 1974. "Geographic Patterns in Temperate American Ferns and Some Relationships in Thelypteris." American fern journal 64, 99-104. https://doi.org/10.2307/1546825.

View This Item Online: https://www.biodiversitylibrary.org/item/100124

DOI: https://doi.org/10.2307/1546825

Permalink: https://www.biodiversitylibrary.org/partpdf/230359

\section{Holding Institution}

Missouri Botanical Garden, Peter H. Raven Library

\section{Sponsored by}

Missouri Botanical Garden

\section{Copyright \& Reuse}

Copyright Status: In copyright. Digitized with the permission of the rights holder.

License: http://creativecommons.org/licenses/by-nc-sa/3.0/

Rights: https://biodiversitylibrary.org/permissions

This document was created from content at the Biodiversity Heritage Library, the world's largest open access digital library for biodiversity literature and archives. Visit BHL at https://www.biodiversitylibrary.org. 